$\begin{array}{ll}\text { Kastamonu Eg̈tim Dergisi } & \text { Başvuru Tarihi/Received: } 01.12 .2017 \\ \text { Kastamonu Education Journal } & \text { Kabul Tarihi/Accepted: } 25.04 .2018 \\ \text { Ocak } 2019 \text { Cilt:27 Sayı:1 } & \text { Dol: } 10.24106 / \text { kefdergi.2420 } \\ \text { kefdergi.kastamonu.edu.tr } & \end{array}$

\title{
Okul Yöneticilerine Göre Öğretimsel Hesapverebilirlik Olgusunun Nitel
} Analizi

\section{Qualitative Analysis of The Instructional Accountability Phenomenon Based on The School Administrators' Views}

\section{Öz}

\author{
Kamil YILDIRIM², Şenyurt YENIPINAR ${ }^{3}$
}

Okul yönetimlerinden, öğretimsel liderliğe eşlik eden hesapverebilirlik talepleri artma eğilimindedir. Bu çalışmanın temel amacı, okul yöneticilerinin perspektifiyle öğretimsel hesapverebilirlik olgusunun, okullarda nasıl deneyimlendiğini betimlemektir. Nitel araştrrmanın olgubilim deseni kullanılarak aşamalı teknikle önce etkileşimli ortamlarda odak grup görüşmesiyle $(n=8)$ ardından etkileşimsiz ortamlarda yarı-yapılandırılmış görüşmelerle $(n=20)$ veriler toplanmıştır. Katılımcılar, 2017 Nisan-Mayıs döneminde Aksaray ili merkez, ilçe ve köylerinde çalışan okul yöneticilerinden maksimum çeşitlilik sağlamak için kasıtlı şekilde belirlenmiştir. Veriler, içerik analiziyle incelenerek sonuçlara ulaşılmıştır. Çalışma sonunda, okullarda bilinçli, sistematik bir öğretimsel hesap sorma-verme işleminin gerçekleşmediği; kazanımların tam edindirilemediği; bu konuya yeterli önem verilmediği saptanmıştır. Kazanımların edinilme düzey ve kalitesi hakkındaki belirsizlik dikkate alınarak okullarda geçerli ve güvenilir bir öğretimsel hesapvermenin gerçekleşebilmesi için öneriler geliştirilmiştir.

Anahtar Kelimeler: Öğretimsel hesapverebilirlik, nitel araştırma, okul yöneticileri.

\section{Abstract}

Demanding for accountability accompanied to instructional leadership from school administration has been increasing. The main purpose of this study was to find out how instructional accountability experienced in schools based on the perspective of the school administrators. Utilizing phenomenology design in qualitative research, we collected data through a stepwise manner including focus-group interviews $(n=8)$ as interaction environment then semi-structured interviews $(n=20)$ as individually controlled environment techniques. To be able to satisfy the maximum diversity, participants were intentionally selected among school administrators working in city centrum, counties and villages in Aksaray province in April-May, 2017. By implementing the content analysis, we had the results. At the end of the study, we conceived the lack of instructional accountability functioning consciously and systematically in schools and educational acquisitions were not fully gained furthermore this issue was not given importance. A valid and reliable accountability mechanism about the level and quality of students' learning acquisitions was absent. We developed suggestions for establishing a valid and reliable accountability in schools.

Keywords: Instructional accountability, qualitative research, school administrators.

1. Bu çalışma 31.01-02.02.2018 tarihlerinde Kayseri'de gerçekleştirilen I. Uluslararası Sosyal Bilimler Kongresinde sözlü bildiri olarak sunulmuştur.

2. Aksaray Üniversitesi, Eğitim Fakültesi, Türkiye; https://orcid.org/0000-0002-5212-3905

3. Aksaray Üniversitesi, Eğitim Fakültesi, Türkiye; https://orcid.org/0000-0002-0568-876X

Atıf / Citation: Yıldırım, K., \& Yenipınar, Ş. (2019). Okul yöneticilerine göre öğretimsel hesapverebilirlik olgusunun nitel analizi. Kastamonu Education Journal, 27(1), 151-162. doi:10.24106/kefdergi.2420 


\section{Extended Abstract}

Related laws (5018, 4982, and 5176) has already established the basis of accountability in Turkish Public Administration. As a unit of public administration, schools are objective of these legal arrangements. An accountability process mainly answers the five basic questions: why, what, who-whom, how, what reward or sanction. In education system, accountability works in the legal, normative and output dimensions. Output basis accountability uses the students' learning acquisitions that also have a key role in school development. School administrators have increasingly been under pressure to be instructional leaders accompanied to instructional accountable. Because it is expected them to contribute in developing students' learning on which schools function. Instructional accountability refers to enable accountability about the students' learning acquisitions. In spite of its importance, literature review could not display any research focused directly on the instructional accountability. This research attempted to contribute in filling this research gap by examining the phenomenon of instructional accountability in schools based on the school administrators' views.

We carried out a qualitative research including two sequential data collecting techniques. We first implemented focus group interview $(n=8)$ then semi-structured interviews $(n=20)$. Participants were intentionally selected from school administrators working in city centrum, counties and villages in Aksaray province in the term of April-May, 2017. In this study, maximum diversity means differences regarding gender, experience, school size, location and school level. We considered the five basic elements of accountability in education that are why, what, who-whom, how, what rewards and sanctions in implementing the data collection processes. Focus group interview was carried out by first informing them about the phenomenon and following their permission we recorded the interviews. Researchers, as moderators, asked extra questions considering responses of participants to deepen into their experiences related with the phenomenon. Based on the focus-group interviews, researchers designed semi-structured interview form then it was implemented to participants who did not take place in focus-group interview. We held face to face interviews with participants in their genuine work environment. In generally each interview took 40 minutes. Researchers independently analysed contently the voice recorded and semi-structured forms as transforming the data into Microsoft word and Microsoft excel, then they compared their analysis and produced a common data form. Researchers grouped the data into classification designed based on the five elements of accountability. We kept the same expressions in the same group. We satisfied the validity and reliability as conducting the diversity in participants, sequential data collection processes, intra-consistency for data coming from both interview techniques, texting the questions and participants' direct expressions, and independent analysis.

Nearly all participants in both interviews techniques agreed upon the necessity of instructional accountability. But they informed that a lack of systematic accountability process. The concept of accountability has not been fully conceived, too. They did not know the objectives in the curriculum satisfactorily and they perceived that students partially achieved these learning objectives. But nearly anybody demanded an account about the level and quality of students' learning acquisitions. Parents very rarely demanded information about performances of their children. However, school administrators gave account to upper administrators on many issues such as school building, formal correspondence other than students' learning. Participants did not know how they account on students' learning and they put forwarded some obstacles for instructional accountability including the lack of suitable legal infrastructure, the need for valid and reliable assessment and evaluation system, and reporting accordingly, and lack of incentive mechanism. They mentioned many differences in regarding backgrounds of students, their readiness, teachers' competencies as hindrances of instructional accountability. They suggested performance based incentive mechanism as precondition. They also expressed the inconsistency between objectives in the curriculum and students' ability, need and interest.

We concluded that the phenomenon of instructional accountability has no place among the jobs of school administrators. As previous studies pointed out, in generally "accountability", specifically "instructional accountability" has not been conceived fully (Acar, 2013; Bülbül, 2011; Kardaş, 2016; Özen, 2011). The main reason suggested as the cause of this result is the lack of functional instructional accountability promoted by the legal infrastructure. Keeping the level and quality of students' learning acquisitions out from the focus point of school indicated the "goal shift" for the school. The importance attributed on achievement of nationwide examinations surpass the students' learning development (Ertan-Kantos, 2010; Özen, 2011). While they are known as misrepresenting of students' learning (Darling-Hammond, 2007; Özen, 2011; TEDMEM, 2014; Ladd, 2016), most of school administrators put emphasis on the role of such test based accountability. On the other hand, some alternative ways have been suggested to collect information about their learning development such as daily observations, conversations with them and the blended of different assessment systems (Elgart, 2016; Kardaş, 2016; Ladd, 2016). And teachers' coteries can also provide valuable information about the level and quality of students' learning acquisitions. Based on the results we developed some suggestions for establishing instructional accountability in schools. All shareholders of school education have to be informed about it, then detailed sub-legal infrastructure was put into practice and workable instructional accountability should be introduced. 


\section{Giriş}

Hesapverebilirlik, sorumluluğu da içine alan bir kavramdır. Sorumluluk ise kendi yetki alanına giren herhangi bir olayın sonuçlarını üstlenmektir (tdk.gov.tr). Türk sosyal ve kültürel hayatında yeri olan bu kavramın kamu yönetiminde, ilgili kanunlarla $(5018,4982,5176)$ yasal altyapısı oluşturulmuştur (Acar, 2013; Bülbül, 2011). Hesapsorma-vermenin önkoşulu, hizmet veya ürün hakkında bilgi sahibi olmaktır. Eğer hesapsorma-verme (HS-V) ile yükümlü taraf, sorumlu olduğu işin süreci ve sonucu hakkında bilgi sahibi değilse hesabı veremez. HS-V gerçekleşmesi için tarafların yükümlendikleri işin kural ve koşullarını biliyor olmaları gerekir. Söz konusu kural ve koşullar, işin tanımlanıp görevlendirme yapılması, işin gerçekleştirilme süreci ve işin tamamlanması süreçlerini kapsar. HS-V işleminde kim, kime, neyin hesabını nasıl verecek ve sonucunda ne olacak sorularının karşıık bulması gerekmektedir (Acar, 2013; Balcı, 2001). HS-V aracılığıyla kural, koşul ve süreç bilgisinin edinilmesi bile üstlenilen sorumluluğun yerine getirilmesine olumlu katkı yapar. Çünkü bilinen süreçlerin uygulanması, bilinmeyenlere göre daha çok gerçekleştirilme olasılığına sahiptir.

Hesapverme kavramı, yarı-kamusal bir hizmet olarak görülen eğitime uygulandığında eğitimsel hesapverebilirlik kavramıyla karşılaşıımaktadır. Eğitim alanında mevzuat temelli, mesleki norm temelli ve sonuç temelli olmak üzere üç farklı HS-V önerilmektedir (Ertan Kantos, 2010; Özen, 2011). Eğitimde hesapverebilirlik "eğitim paydaşlarını ilgilendiren ve etkileyen karar, işlem ve eylemlere dair bilgi ve gerekçe sunma yükümlülüğüdür" (Acar, 2013). Eğitimde HS-V sürecinde çıkt ve sonuçlar (öğrencilerin/okulların performansları) ile eğitimcilerin kurallara, mesleki norm ve standartlara uygun davranışları hakkında bilgi edinilmesi gerekmektedir (Acar, 2013; Anderson, 2005; Öntaş ve Atmaca, 2016). Eğitimde yaygın şekilde öğrencilerin öğrenmesi temelinde sonuçlara dayalı HS-V uygulanmaktadır (Anderson, 2005; OECD, 2016).

Hesapverebilirlik, sonuçları kontrol edilebilen ve ölçülebilen alanlarda uygulanabilir. Eğitimde hesapverebilirlik kavramı genel, soyut ve oldukça geniş bir kapsamı içine almaktadır. Formal ve informal yollarla her yerde gerçekleştirilebilen eğitim hizmetinden ve ürününden sorumlu, makro ve mikro düzeyde örgütler ve sistemlerle ilişkili paydaşlar, eğitimsel hesapverebilirlik kapsamına girebilir. Tarihsel süreçte eğitimde hesapverebilirlik öğretimsel alana doğru evrilmektedir (Bülbül ve Demirbolat, 2014). Çünkü öğretimsel konularda hesap verebilir ve sorabilir düzeyde olmak, eğitime hizmet etmektedir. Okuldaki işgörenlerin öğretimsel olarak hesapverebilir olmaları, öğrencilerin potansiyellerini gerçekleştirmelerinde daha iyi firsatlar sunacaktır (Gündüz ve Göker, 2017). Hesapverebilirlik kavramının okullardaki öğretim sürecine uygulanması biçiminde tanımlanabilecek öğretimsel hesapverebilirlik, eğitimsel hesapverebilirliğe göre daha kontrol edilebilir ve ölçülebilir bir kapsama sahiptir.

Okullar, eğitim sisteminin yönetsel birimi olarak, yukarıda anılan kanuni düzenlemelere tabidir. Okul yönetimleri yasal, mesleki ve sonuç temelli HS-V ile yükümlüdür (Leithwood, Steinbach ve Jantzi, 2002). Okulda hesap sorma-verme (HS-V) faaliyetlerinin temel amacı öğretim sürecindeki işlemlerin tam yapılmasıyla bütün öğrenciler için daha iyi eğitimin verilmesidir (Parkes ve Stevens, 2003). Okulların nihai amacı, öğrencileri kapasitelerinin sonuna kadar geliştirmek suretiyle onların yaşam kalitelerini artırmaktı (Fidan ve Baykul, 1996). Öğretim etkinlikleri bu amaç için kilit önemdedir. Okullar, amaçlarına ulaşmak için öğrencilerin öğrenmeleri gereken bilgi beceri ve tutumları öğrenebilecekleri faaliyetleri tasarlarlar ve sürecin niteliğini kontrol ederler (Schlechty, 2005). Öğretimsel hesapverebilirlik (ÖHS-V) açısından öğretim programında yer alan amaç ve kazanımların edinilme durumu önemli işlev görmektedir (Özen, 2011). Örgün öğretim kapsamındaki okullar için öğretim programındaki kazanımlar, öğretimin yapılma şekli kadar, öğretimin etkililiği hakkında da bir ölçüt (referans, kriter) rolü üstlenmektedir. Öğretim faaliyetlerinin girdi, süreç ve çıkt aşamalarında öğrenci, öğretmen, veli ve yönetici hesap sorma ya da verme paydaşlarıdır (Öntaş ve Atmaca, 2016). Bu çerçevede öğretimsel hesapverebilirlik, okullarda öğretimle ilişkili gerçekleştirilen işlemler hakkında bilgi ve gerekçe sunulması yükümlülüğü biçiminde tanımlanabilir. Bir süreç hakkında hesap verebilmek o süreci bileşenlerine ayırarak anlamayı gerektirir (Schlechty, 2005). ÖHS-V açısından kazanımların gerçekleştirilme durumu çıktı ve sonuç odakı hesapverme türünü olanaklı kılmaktadır.

Kazanımların edinilme düzey ve kalitesi gösterge alınarak okulda gerçekleştirilen öğretim hakkında, okul yöneticileri, öğretmenler, veliler, öğrenciler, yakın çevre ve eğitim üst düzey yöneticileri HS-V tarafları olarak sıralanabilir. Okul yönetimleri, günümüzde artan şekilde okul gelişiminin baş sorumlusu ve aktörleri olarak belirmekte; onlardan ÖHS-V talepleri de artmaktadır (OECD, 2014). Okul yöneticileri, okullarında gerçekleştirilen öğretimin etkililiği; bir başka söyleyişle öğrencilerin hedeflenen bilgi, beceri ve tutumları kazanmaları hakkında hesapvermek durumundadırlar. Okul yöneticilerinin, okullarındaki öğretime ilişkin hesapsorma-verme durumu hakkında geçerli güvenilir bilgi ihtiyacı bulunmaktadır. Fakat literatür taraması, Türkiye'de hesapverebilirlik üzerine yapılan çalışmaların sayısal artışına rağmen doğrudan "öğretimsel hesapverebilirlik" konusuna odaklanmış ulusal düzeyde herhangi bir çalışmayı göstermemiştir. Erişilen çalışmaların tamamı tarama modelinde nicel çalışmalar olup Türk eğitim sisteminin genelinde (Bülbül ve Demir- 
bolat, 2014), denetim sürecinde (Göker ve Gündüz, 2017), ilköğretim ya da ortaöğretim kurumlarında eğitimsel hesapverebilirlik (Ertan Kantos, 2010; Kalman ve Gedikoğlu, 2014; Özen, 2011) ve öğretmenlerin kendilerini öğrenci başarısı açısından hesapverebilir görme durumuna (Bakioğlu ve Salduz, 2014) odaklıdır. Bu çalışmalarda ulaşılan sonuçlara göre Türkiye'de eğitim alanında hesapverebilirliğin uygulanmadığı ve gerçek anlamda içselleştirilmediği bildirilmektedir. Literatür taraması, öğretimsel hesapverebilirlik odaklı bir araştırma eksikliğini göstermektedir. Oysa bu konuda yapılacak çalışmalar düzeltici-geliştirici girişimlere yol açabilir; böylece ÖHS-V gerçek amacı olan öğrencinin gelişimine hizmet edebilir. Hesapverebilirlik kavramı ve ilkelerinin okullardaki öğretime uygulanması ile araştırmanın sonuçları, uygulamada öğretimin kalitesinin iyileştirilmesine ve bu yolla eğitim sisteminin daha etkili hale gelmesine katkı sağlayabilir.

\section{Araştırmanın Amacı}

Türk Milli Eğitim sisteminde, okullarda performans yönetimi modeli ve okul gelişim modeli gibi HS-V gerektiren girişimler (Erdağ, 2017; Ertan-Kantos, 2010) olmasına karşın HS-V olgusunun problemli bir alan olduğu saptanmıştır (Bülbül, 2011; Karakaya, 2004; Özen, 2011). HS-V'nin sistemin hangi boyutlarında ve nasıl deneyimlendiği; özellikle okullardaki durumunu ortaya koyan çalışmalara intiyaç duyulmaktadır (Bülbül, 2011). Bu çalışma ile okullarda öğretimsel hesapverebilirlik olgusunun okul yöneticilerinin deneyimlerine dayalı incelenmesi amaçlanmıştir.

\section{Yöntem}

Bu araştırma nitel araştırma desenlerinden olgubilim (fenomenoloji) deseninde gerçekleştirilmiştir. "Olgubilim deseni farkında olduğumuz ancak derinlemesine ve ayrıntılı bir anlayışa sahip olmadığımız" konulara odaklanmaktadır (Yıldırım ve Şimşek, 2011). Bu çalışmada belirlenen öğretimsel hesapverebilirlik olgusu hakkında okul yöneticilerinin deneyimleri incelenmiştir. Öğretimsel hesapverebilirlik konusunda okul yöneticileri öğretimsel amaçların gerçekleştirilmesinden yasal olarak sorumludurlar (MEB, 2018a; MEB, 2018b). Çalışmada görüşme yönteminin odak grup görüşmesi ve yarı-yapılandırılmış görüşme teknikleri uygulanmıştır.

\section{Çalışma Grubu}

Bu çalışmada belirlenen öğretimsel hesapverebilirlik olgusu üzerinde etkili olabilecek okulun yerleşim yeri, okulun kademesi, okul büyüklüğü, yöneticilikte toplam deneyim ve mevcut okuldaki yöneticilik deneyimi ile cinsiyet değişkenleri dikkate alınarak maksimum çeşitlilik sağlamak amacıyla kathlımcılar kasıtlı olarak seçilmiştir. Bunlara ek olarak katılımcıların belirlenmesinde gönüllülüğün esas alınmış olması, bu yöneticilerin okullarındaki öğretime ilişkin bilgi alma ve bilgi vermede istekli olduklarının ve yüksek motivasyonlu yöneticiler olduklarının göstergesi olarak varsayılmıştır. Aksaray ilinde 2017 Nisan-Mayıs döneminde okulöncesi, ilkokul, ortaokul ve lise kademesinden köy, ilçe ve şehir merkezindeki farklı büyüklüklerdeki okullarda görevli farklı deneyim sürelerine sahip okul yöneticileri çalışmaya katımıştır. Katlımcıların demografik bilgileri Tablo 1'de gösterilmektedir.

\section{Tablo 1. Katilımcıların demografik bilgileri}

\begin{tabular}{|c|c|c|c|c|c|c|c|c|c|c|}
\hline \multirow{2}{*}{ Özellikler } & \multicolumn{5}{|c|}{ Odak Grup Görüşmesi } & \multicolumn{5}{|c|}{ Yarı-yapılandırılmış Görüşme } \\
\hline & 1 & 2 & 3 & 4 & Toplam & 1 & 2 & 3 & 4 & Toplam \\
\hline $\begin{array}{l}\text { Cinsiyet } \\
\text { 1: Kadın; 2: Erkek }\end{array}$ & - & 8 & - & - & 8 & 4 & 16 & - & - & 20 \\
\hline $\begin{array}{l}\text { Toplam deneyim (yıl) } \\
\text { 1:5 ve daha az } 2: 6-10 ; 3: 11-15 ; 4: 16^{+}\end{array}$ & - & 2 & 3 & 3 & 8 & - & 2 & 5 & 13 & 20 \\
\hline $\begin{array}{l}\text { Kademe } \\
\text { 1:Okulöncesi; 2:Illkokul; 3:Ortaokul; 4:Lise }\end{array}$ & - & 4 & 3 & 1 & 8 & 2 & 6 & 6 & 6 & 20 \\
\hline $\begin{array}{l}\text { Mevcut okuldaki deneyim } \\
\text { 1:Ilk yıl; 2:1-2 yıl; 3:3-5 yıl; 4: } 6^{+}\end{array}$ & - & 2 & 6 & - & 8 & 1 & 4 & 11 & 4 & 20 \\
\hline $\begin{array}{l}\text { Okul büyüklüğü (Öğretmen sayısı) } \\
\text { 1:Küçük; 2:Orta; 3: Büyük }\end{array}$ & 2 & 4 & 2 & - & 8 & 6 & 7 & 7 & - & 20 \\
\hline $\begin{array}{l}\text { Okul bulunduğu yerleşim yeri } \\
\text { 1:Köy; } 2: I I l c ̧ e ; 3: \text { II }\end{array}$ & 2 & 2 & 4 & - & 8 & 3 & 3 & 14 & - & 20 \\
\hline
\end{tabular}

Odak grup görüşmesine yönetim deneyimi fazla olan ve ağırlıkla ilkokul ve ortaokul kademesinde görev yapan okul yöneticileri (iki müdür yardımcısı ve altı müdür) katılmıştr. Bunların ikisi köy, ikisi ilçe ve dördü şehir merkezinde görev yapmaktaydılar. Odak grup görüşmesine katılan yöneticilerin ikisi küçük (15 ve daha az öğretmenli), dördü orta büyüklükte (16-30 öğretmenli) ve ikisi de büyük (31 ve daha fazla öğretmenli) okuldu. Yarı-yapılandırımış görüşme yapılan okul yöneticilerinden dördü kadındır. Yöneticilerden ikisi en az alt yıllık yöneticilik deneyimine sahipken 13'ü en az 16 
yıldır yöneticilik yapmaktaydı. Katılımcıların yalnızca biri halen çalıştı̆ı okulda ilk yılını çalışırken çoğunluk ( $N=11$ ) en az üç yıldır aynı okulunda çalışmaktaydı. Okul yöneticilerinin altısı küçük okulda, yedisi orta büyüklükte ve yedisi de büyük okulda çalışmakta iken; yarı-yapılandırılmış görüşme yapılan yöneticilerden çoğu ( $N=14)$ şehir merkezindeki okullarda çalışmaktaydı.

\section{Verilerin Toplanması}

"Olgubilim araştırmalarında veri kaynakları, olguyu yaşayan ve bu olguyu dışa vurabilecek veya yansıtabilecek bireyler ya da gruplardır" (Yıldııım ve Şimşek, 2011). Bu çalışmada veri kaynakları okul yöneticileridir çünkü okul yöneticileri yönetim görevlerinden dolayı okuldaki öğretimin gerçekleştirilmesine ilişkin hesapverme-sorma yükümlülüğü taşıyan en başta gelen bireylerdir. Veriler odak grup görüşmesi ve yarı-yapılandııılmış görüşme yöntemleriyle toplanmıştır. Olgunun okullarda nasıl yaşandığını keşfetmek ve kapsamını tespit etmek amacıyla öncelikle odak grup görüşmesi yapılması tercih edilmiştir. Odak grup görüşmesini temel alarak yöneticilerin etkileşimsiz ortamda bireysel görüşlerini de belirleyebilmek amacıyla yarı-yapılandırılmış görüşmeler yapılmıştır. Görüşmelerin gerçekleştirilmesinde Yıldırım ve Şimşek (2011: 168) tarafindan belirtilen görüşme yönteminin ilkeleri izlenmiştir. Buna göre; "görüşme sorularında akışa göre değişiklik yapma, soruları konuşma tarzında sorma, teşvik etme ve geri bildirimde bulunma, süreci kontrol etme ve yansız-empatik olma" ilkeleri uygulanmıştr. Önce sekiz okul müdürünün katılımıyla odak grup görüşmesi yapılmış, ardından 20 okul yöneticisi ile yarı-yapılandırılmış görüşmeler gerçekleştirilmiştir. Odak grup görüşmelerinde katılımcılar birbirlerinin fikirlerinden ve düşüncelerinden faydalandıkları için yeni ve farklı fikirler ortaya çıkabilmektedir (Çokluk, Yılmaz ve Oğuz, 2011). Odak grup görüşmesi 2017 yılı Nisan ayında bir çalışma gününün sonunda saat 17.00-20.00 arasında kapalı bir mekânda (Aksaray Öğretmenevi) gerçekleştirilmiştir. íki saat yirmi dakika süren odak grup görüşmesi araştırmacıların moderatörlüğünde gerçekleştirilmiştir.

Odak grup görüşmesinde sorulacak soruların saptanmasında literatüre dayalı olarak araştırmacılar tarafindan geliştirilen sorular üç okul müdürüne yöneltilerek onların deneyimlerinden yararlanılarak düzenlenmiştir. Araştrrmanın amacına hizmet edecek şekilde okullarda öğretimsel hesapverebilirliğin nasıl deneyimlendiğini ortaya çıkarmak üzere şu soruların sorulması kararlaştrıımıştı: $i$ ) Kazanımların gerçekleşme durumu ile ilgili hesap vermenin gerekli olduğunu düşünüyor musunuz? ii) Okulunuzda bir öğretim yılında öğretim programındaki kazanımların ne kadarı gerçekleştirilmektedir? iii) Kazanımların gerçekleşme durumu ile ilgili siz hesap veriyor musunuz? iv) Kimlere hesap veriyorsunuz (Veli, üst yöneticiler, öğrenci, ...)? v) Bu konuda kimler sizden hesap vermenizi talep ediyor?

Odak grup görüşmesinde öncelikle ÖHS-V olgusu hakkında katılımcıların ön bilgileri alınarak bilgilendirilmişler ardından okullarında bu olgunun gerçekleşme durumu hakkında deneyimleri sorulmuştur. Sorular katlımcıların tamamına yönelik olarak sorulmuş, görüşlerini belirtmek isteyen her katılımcıya söz hakkı verilmiştir. Bir başkasının görüşünden hareketle görüşlerini belirtmek isteyenlere tekrar imkân verilmiştir. Araştırmacılar yaptıkları açıklamalar ve sordukları sorularla katılımcıların olguya yönelmeleri ve derinleşmelerini sağlamışlardır. Önceden planlanmadığı halde görüşme sürecinde ihtiyaç duyulan şu sorular da sorulmuştur: i) Okulunuzda öğrencilerin edinmesi gereken kazanımlar hakkında ne düzeyde bilgi sahibisiniz? ii) Bu kazanımların öğrenciler tarafindan edinilme düzeyi ve kalitesi hakkında deneyimleriniz nedir? iii) Öğretim programındaki kazanımların öğrenciler tarafından edinilmesi konusunda verilen hesabın yeterli olduğunu düşünüyor musunuz? Gerekçelendirebilir misiniz?

Odak grup görüşmesinde elde edilen bulgulardan yararlanılarak yarı-yapılandırılmış görüşme formu hazırlanmıştır. Yarı-yapılandııımış görüşme, odak grup görüşmesine katılmamış farklı katlımcılarla çalışma ortamlarında yüz yüze gerçekleştirilmiştir. 2017 Mayıs döneminde görüşmeler tamamlanmıştı. Öğretimsel hesapverebilirlik kavramının literatürde henüz yeni olması nedeniyle ve araştırma sürecinde kavramsal anlam birlikteliğini sağlamak amacıyla katılımcılara öğretimsel hesapverebilirlik hakkında ön bilgi verilmiş ve olgu hakkında genel bir görüşme yapılarak yarı-yapılandırılmış formda yer alan açık uçlu sorular katılımcılara yöneltilmiştir. Bu süreçte bir örnek form katılımcıda bulunurken araştırmacılardan biri soru sormuş; diğeri katılımcının cevaplarını anında yazılı olarak kaydetmiştir. Görüşmenin sonunda kayıtlar katılımcılara teyit ettirilmiştir. Bir yarı-yapılandırılmış görüşmenin tamamlanması ortalama 40 dakikayı almıştı. Katılımcılara şu sorular sorulmuştur: i) Okulunuzda öğrencilerin edinmesi gereken kazanımlar hakkında ne düzeyde bilgi sahibisiniz? ii) Size göre okulunuzda bir öğretim yılında öğretim programındaki kazanımların ne kadarı gerçekleştirilmektedir? iii) Bu kazanımların öğrenciler tarafindan edinilme düzeyi ve kalitesi hakkında deneyimleriniz nedir? iv) Kazanımların gerçekleşme durumu ile ilgili hesap vermenin gerekli olduğunu düşünüyor musunuz? v)Kazanımların gerçekleşme durumu ile ilgili siz hesap veriyor musunuz? vi)Kimlere hesap veriyorsunuz? (Veli, üst yöneticiler, öğrenci, ...) vii) Bu konuda kimler sizden hesap soruyor? viii) Öğretim programındaki kazanımların öğrenciler tarafından edinilmesi konusunda verilen hesabın yeterli olduğunu düşünüyor musunuz? Gerekçelendirebilir misiniz? 


\section{Verilerin Analizi}

Odak grup görüşmesinde katılımcıların izni alınarak ses kaydı yapılmıştır. Kayıt deşifre edilerek Microsoft Word programına aktarıımıştır. Ses kaydının çözümlenmesinde seçici dinleme ile öğretimsel hesapverebilirlik olgusuna ilişkin ifadeler tespit edilmiştir. Araştırmacılar, birbirlerinden bağımsız şekilde, yaptıkları çözümlemeleri karşılaştırarak ortak bir form üretmişler ve içerik analizi gerçekleştirmişlerdir. İçerik analizinde katlımcılar cinsiyete göre takma adlarla kodlanmıştı (Ali, Ayşe vb.). İçerik analizinde ulaşılan temalar "Bilinç, kim-kime, nasıl ve sonuç" şeklinde adlandırımıştır. Yarı-yapılandırılmış görüşmede ise görüşme formlarının "Microsoft excel çalışma programı"na aktarılmasıyla veriler incelenmiştir. Araştırmacılar birbirlerinden bağımsız içerik analiziyle bilgi parçalarını tespit etmiş ve bunları karşılaştrarak önceden saptanmış temalara göre gruplandırmışlardır. İçerik analizinde araştırmacıların temalandırma başlıkları i) Hesapverme-sorma bilinci, ii) Neyin hesabı verilecek, iii) Kim-kime hesap verecek, iv) Nasıl hesap verilecek ve v) Sonuç ne olacak şeklindedir. Belirlenen bu temalar, bilinç teması dışında Acar (2013) tarafindan önerilen "eğitimde HS-V aşamaları" ile örtüşmektedir. Veriler temelinde HS-V bilinci teması da eklenmiştir. HS-V bilinci kavramsal hâkimiyet, önemine inanma, mevcut duruma ilişkin farkındalık olmak üzere üç alt unsuru içermektedir.

\section{İnandırıcılık ve Tutarlılık}

Nitel çalışmalarda geçerlik ve güvenirlik karşılığında inandırıcılık ve tutarlılık kullanılmaktadır. Bu çalışmada odak grup görüşmesi ve yarı-yapılandırılmış görüşme sonuçlarındaki uyumluluk, farklı görüşme tekniklerinin aşamalı biçimde kullanılması, bu görüşmelerde katılımcı çeşitliliğinin sağlanması ve farklı görüşlerin ortaya çıkmasıyla doğrudan alıntılara yer verilmesi ve katılımcı teyidi inandırıcılığı desteklemektedir. Görüşme kayıtlarının paylaşılabilir olması, yöneltilen soruların belirlenmesi yönteminin ortaya konulması, veri toplama ve analiz süreçlerinin açıklanması, yanlılığı önleyici bağımsız çözümlemeler yapılmış olması ise tutarlılığı destekleyici yönlerdir. Bunlara ek olarak amaçlı örnekleme, katılımcılar hakkında bilgi, görüşsme ortamlarının betimlenmesi inandırıcılı̆̆ı ve tutarlılı̆ı desteklemektedir (Yıldırım ve Şimşek, 2011: 299-308).

\section{Bulgular ve Yorumlar}

Bu bölümde öğretimsel hesapverebilirlik olgusuna ilişkin okul yöneticilerinden elde edilen verilerin analizi sonucunda elde edilen temaların dayanağı olan bulgular sunulmaktadır. Bu temalar i) bilinç, ii) ne, iii) kim-kime, iv) nasıl ve v) sonuç temalarıdır. Ayrıca odak grup görüşmesi ve yarı yapılandırılmış görüşme bulgularının, temalara göre özetlenmiş hali Tablo 2'de karşılaştırmalı şekilde verilmiştir.

Katılımcıların geneli ÖHS-V'nin önemli ve gerekli olduğunu; fakat ÖHS-V'nin gerçekleşmediğini, üstelik nasıl yapılacağını bilemedikleri gibi kazanımların edinilme durumuna ilişkin geçerli-güvenilir belgelendirmenin eksikliğini belirtmişlerdir. ÖHS-V'nin üst yönetimlerin gündeminde olmadığı bildirilmekte ve ağırlıklı olarak ikili öğretimden normal öğretime geçiş, fiziki kapasitenin artıııması, kademeler arası geçişte uygulanacak sınavların düzenlenmesi gibi konulara odaklanıldığı açıklanmaktadır. Ali kodlu yönetici: "Bizden yalnızca okulun fiziki durumu ya da yazışmalarla ilgili hesap soruluyor. Bugüne kadar hiçbir idarecimiz bizden sizin okulda kazanımlar neden edindirilememiş diye hesap sormadı" şeklinde açıklama yapmaktadır.

Bir başka okul müdürü görüşünü (Ahmet) "Hesapvermek gerekli ama bunu nasıl yapabileceğimizi bilmiyoruz. Hem de yaptrım yok. Bu durum örtülü, üstelik bunu yapmamızı gerektiren bir talep de yok" şeklinde ifade etmiştir. Okul yöneticileri öğretim programına ne kendilerinin ne de öğretmenlerin tam anlamıyla hâkim olmadıklarını, öğretim programındaki değişiklikleri öğretim uygulamalarına yansıtmadıklarını, yapılagelen öğretimin sürdürüldüğünü ifade etmişlerdir. Örneğin Mehmet kodlu katılımcı "Öğretim programına yeterince hâkim değiliz. Programa hâkim olmadığımız için öğretimi de çok bilinçli şekilde yerine getiremiyoruz" açıklamasını yapmıştr.

Hesapverme sürecini açıklamaya çalışan bir başka yönetici (Ömer) "Öğretmen idareciye, idareci de üst yönetime hesap vermelidir. Fakat yönetici bunun öneminin farkında değil" görüşünü ileri sürmüştür. Okul yöneticileri ÖHS-V önünde bir dizi engel olduğunu açıklamışlardır. Öğrencilerin kazanımları edinme durumlarını tespit edebilecek geçerli-güvenilir ölçme-değerlendirme ve belgelendirmenin olmadığı, öğrencilerin yerleşim yeri farklılıkları ve hazırbulunuşluk seviyelerindeki farklııklar ile öğretmenlerin kazanımları öğretime aktarmadaki yeter(siz)likleri vurgulanmıştır. Ahmet kodlu katılımcı öğretim programındaki kazanımların bazı öğrenciler için kolay bazı öğrenciler için zor olabildiğini vurgulamış; Hasan ise "Öğretim programındaki kazanımları öğretime aktarmakta sorun yaşıyoruz yani müfredat ile öğretim uygulamaları arasında uyum yok" açıklamasını yapmıştı. Bu doğrultuda Mehmet kodlu katılımcı "MEB fiziksel etkinlikler dosyasını oluşturup okullara gönderdi. Bu dosyadaki etkinliklerin oldukça iyi olduğunu düşünüyorum fakat bunlar yapılmıyor" şeklinde örneklemiştir. Hüseyin kodlu katılımcı ise "Köylerde örneğin Ingilizce dersinde kazanım tam verilemiyor. 
Kazanım için öğretmenin sınıfta yaptı̆̆ı öğretim etkinliği önemli fakat öğretim yapılıyor mu, kazanım veriliyor mu? Eh işte veriliyor" açıklamasını yapmıştr. Halil kodlu yönetici ise "Okulların bazıları büyük olduğundan ve kademelere göre farklı branşlar olduğundan öğretmeni denetlemek ve hesapsormak güç olabiliyor" açıklamasını yapmıştır.

Osman görüşünü: "Bir dersten ne ölçüde kazanım edindiklerini görebilmek için (deneme) sınav yapmak zorundayız" şeklinde belirtmiştir. Ahmet kodlu katlımcı "Denemeler yasak olmasına rağmen biz uyguluyoruz. Aslında üst yöneticiler de sözel olarak bunu teşvik ediyorlar"demiştir. Osman ise denemelerin yararlı olduğunu "Hangi sınıfta hangi öğrencinin hangi dersten hangi kazanımı edinemediğini gösteriyor. Biz de öğretmenden söz konusu kazanım için nasıl bir çalışma yaptığını sorabiliyoruz" şeklinde açıklamıştır. Mehmet kodlu katılımcı da "Bir hocanıma, deneme sonuçlarını analiz edip etmediğini sordum. Yok, yapmadım deyince çocukların hangi kazanımlarda sorunlu olduklarını görüp buna uygun önlemler almasını istedim" açıklamasını yapmış ve bunun işe yaradığını eklemiştir.

Ahmet: "TEOG sonuçlarına göre öğretmenden hesap sorulabiliyor. Okul müdürü de kendisinden hesap sorulacağını düşünerek önce kendisi ögrretmenden hesap sormak istiyor" derken bir ilkokul müdürü (Ali): "ilkokullarda bir gevşeme var. Herhangi bir sınavın olmaması, öğrencilerin doğrudan ortaokula geçiyor olması kazanımların ne düzeyde edinildiğine ilişkin fikir verebilecek bir uygulamanın olmaması bu duruma yol açıyor" açıklamasını yapmıştı. Deneme sınavlarının ÖHS-V bakımından olumsuz etkilerine de değinilmiştir. Örneğin Hakkı kodlu yönetici "Deneme sınavlarının olumsuz etkisi de var çünkü bu sınavlarda yer alan sorular müfredat dikkate alınarak hazırlanmıyor" açıklamasını yapmıştır.

\section{Tablo 2. Temalara göre çalışmanın bulguları}

\begin{tabular}{|c|c|}
\hline Tema & Odak Grup Görüşmesi \\
\hline$\stackrel{\stackrel{.}{\leftrightarrows}}{\overline{\bar{\infty}}}$ & $\begin{array}{l}\text { ÖHS-V gerekli ve önemlidir. MEB ve çoğu yönetici } \\
\text { ÖHS-V işlevlerinin farkında değildir. Veliler hesapsor- } \\
\text { ma hususunda bilinçli değildirler. }\end{array}$ \\
\hline$\stackrel{0}{z}$ & $\begin{array}{l}\text { Hesapsorma, okulun fiziki durumu ve yazışmalar ko- } \\
\text { nusunda yoğunlaşma; ÖHS-V gerçekleşmemektedir. } \\
\text { Öğretim programındaki kazanımlar yeterince bilinme- } \\
\text { mektedir. }\end{array}$ \\
\hline
\end{tabular}

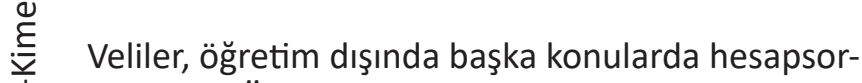 maktadır. ÖHS-V talep edilmemektedir.

\section{Yarı-yapılandırılmış Görüşme}

ÖHS-V gereklidir fakat gerçekleşmemektedir. MEB hesapverebilirliği sınırlandırmıştır. Öğretimsel hesapverebilirlik kavramı tam olarak kavranmamıştır.

Yönetici ve öğretmenler, öğretim programı ve kazanımlarla ilgili tam bilgi sahibi değildirler. Kazanımlar dışında farklı konularda, yönetimin diğer alanlarında HS-V gerçekleşmektedir.

ÖHS-V talep edilmemekte nadiren bilinçli velilere öğretim kalitesi açısından hesapverilmektedir. Öğretim dışındaki konularda en sık veliler, üst yöneticiler ve müfettişlere hesapverilmektedir. Hesapverilecek kişinin niteliklerinin (adaletli, tarafsız, vb) önemi vurgulanmaktadır.

Hesapvermenin nasıl yapılacağı bilinmemekte, ÖHS-V Nasıl hesapverileceği tam bilinmemektedir. Öğretim için sistematik bir mekanizma bulunmamaktadır. ÖHS-V'nin öğretmen-okul yöneticisi-üst yönetici arasında işlemesi önerilmektedir. Performansa bağlı teşvik mekanizması önerilmektedir. ÖHS-V için öğrenci hazırbulunuşluk düzeyi, öğretmenlerin mesleki yeterlikleri, okulun bulunduğu çevre sorun alanları olarak belirtilmektedir. Kazanımların edinilme durumuna ilişkin geçerli, güvenilir sonuçlar üretilmesi, ÖHS-V için ulusal düzeyli bir sınavın olması önerilmektedir. Yasal olmayan deneme sınavları ÖHS-V için kullanılmakta ve resmi başarı belgelerinin (diploma, karne, rapor vb) geçerli ve güvenilir göstergeler olmadığı belirtilmektedir.

\footnotetext{
ํㅡ Okul yöneticileri, hesapsorma sonucu yaptırımın tanımlı olmadığını düşünmektedirler.
}

programındaki kazanımlar öğretime tam anlamıyla aktarılmamaktadır. Kazanımların öğrenciler tarafindan edinilip edinilmediği tam bilinmemektedir. Okulun bulunduğu çevre ve yerleşim yeri ile öğrencilerin hazırbulunuşluğu önemli bir faktör olarak görülmektedir. Kazanımların edinilme düzey ve kalitesi, öğretmenlerin mesleki yeterliklerine bağlanmaktadır. Mevcut yasal düzenlemelerin ÖHS-V için uygun olmadığı düşünülmektedir. Performans değerlendirmesinin ve buna bağlı hizmetiçi eğitimin önemli olduğu vurgulanmıştr. Ulusal düzeyli sınavlara ÖHS-V kapsamında özel önem atfedilmekte, kazanımların edinilme düzey ve kalitesine ilişkin geçerli-güvenilir verilerin üretilmesi gereği vurgulanmaktadır.

Kazanımların edinilme düzeyi ve kalitesi memnuniyet verici değildir. Kazanımların edinilme düzeyinin gerçek kaynağı olarak okulun bulunduğu çevrenin sosyo-ekonomik yapısı işaret edilmektedir. Hesap sorma sonucunda yaptırımın olmadığı belirtilmektedir. Öğretimsel hesapverebilirlik için performans değerlendirmenin gerekliliği belirtilmektedir. 
Bir başka boyutu Osman: "Sene sonu düzenlediğimiz raporlarda kazanımların edindirildiğini belirtiyoruz. Oysa bu kazanımların hangi düzeyde edindirildiği hakkında gerçekte bir bilgimiz yok" şeklinde belirtmiştir. Bu kapsamda Hüseyin kodlu katılımının "409 kişi mezun oluyor ve bunların 374'ü takdir alıyor. Bu durum kazanımların çok iyi düzeyde edindirildiği izlenimi verse de yanıltıcı oluyor" şeklindeki açıklamasını Mehmet: "Bir okulda takdir alan bir öğrenci bir başka okulda dersi zorlukla geçebilir" ifadesiyle desteklemiştir.

ÖHS-V'nin kimler arasında yapılması gerektiğine ilişkin soru kapsamında Hüseyin: "Hesap soran yok, hesap veren de yok. Veliler ise öğretimle ilgili olmayan konularda bilgi talep edebiliyor" açıklamasını yaparken; Osman kodlu katılımcı "Bizler de veliyiz. Kendi çocuğumun okulunda matematik öğretmeniyle görüşmüştüm. Yanlış yapılan soruların çözümleri üzerinde sınıfta durup durmadığını sormuştum. Öğretmen çocuklar istemiyor ki cevabını verince öğretmene çıkışmıştım" açıklamasını yapmış ve veliler bilinçli olmadığından bu konuda hesap soramadıklarını eklemiştir. Hakkı ise: "Kazanımları dikkate alarak öğretmenler hesapvermelidirler. Bunun için performansa bağlı teşvik mekanizmasının da işletilmesi gerekir" açıklamasını yapmıştır.

Yarı-yapılandırılmış görüşmelerde kattlımcıların neredeyse tamamı (N=18) kazanımların gerçekleştirilme durumuyla ilgili olarak hesapvermenin gerekli olduğunu, yapılması gerektiğini belirtmektedirler. Fakat bu konuda bazı sorunlar olduğunu dile getirmişlerdir. Hangi konularda nasıl ve kime hesapverileceği sorunlu alanlar olarak belirtilmektedir ( $N=17)$.

Hesapverilecek kişinin nitelikleri vurgulanmaktadır $(\mathrm{N}=4)$. Örneğin bir katılımcı "Evet hesap verilmeli. Ama kime? Nasıl? Bu hamur çok su götürür. Sorumluluk çok yetki yok. Hesap sorulmalı ama yetkide verilmeli. Hesap soracak kişi adil ve tarafsız olmalı" şeklinde görüşünü ifade etmiştir. Bu konuda bir başka yönü ise bir katılımcı "Evet düşünüyoruz fakat bu hesap verebilirlik ilkokul düzeyinde biraz zor. Ölçme sıkıntısı var. Neye göre nasıl ölçeceğiz." şeklinde vurgulamıştır.

Katilımcıların görüşlerinden hareketle hesapverebilirlik kavramının henüz tam olarak oluşmadığı, yasal temeli olmasına rağmen bunu hayata uygulayabilecek düzenleyici mevzuatın oluşturulmadığı çıkarımı yapılabilir. Bu bağlamda okul yöneticilerinin, kendi okul öğretmenlerinin ölçme ve değerlendirme yeterlikleri ve buna bağlı ortaya konulabilecek değerlendirme sonuçları hakkında kuşkuları olduğu $(\mathrm{N}=15)$, öğretmenlerin bu konudaki becerilerini yeterli görmedikleri söylenebilir.

Yöneticilerin ulusal düzeyli yapılan sınavlarda elde edilen sonuçlara $(\mathrm{N}=17)$, hesapverebilirlik kavramı içinde özel önem atfettikleri belirtilebilir. Okul yöneticileri, öğrencilerin edinmesi gereken kazanımlar hakkında tamamen bilgi sahibi olmadıklarını ama haberdar olduklarını belirtmektedirler $(\mathrm{N}=16)$. Okul yöneticileri öğretim programında yer alan kazanımların öğrenciler tarafindan orta düzeyde edinildiği algısına sahiptirler $(\mathrm{N}=15)$. Bu düzey kazanımların neredeyse yarıya yakının gerçekleştirildiğini ve yarı yakının da kazandırıımadığı şeklinde yorumlanabilir. Kazanımların edindirilme durumu nicel ve nitel yönleri kapsamaktadır. Uygulamada ağılıkla nicel yön dikkate alınırken edinmenin hangi kalitede olduğu gözardı edilmektedir.

Katlımcılar genel olarak kazanımların edinilme düzeyinin memnuniyet verici olmadığını ifade etmektedirler ( $N=15)$. Edinilme kalitesi hakkında ise daha olumsuz bir görüşün ortaya çıktğı söylenebilir ( $N=17$ ). Bu konuda okulun merkezde veya kırsalda bulunmasının önemli bir faktör olduğu vurgulanmaktadır ( $N=19)$. Kazanımların edinilme düzeyinin gerçek kaynağının okulun bulunduğu çevrenin sosyo-ekonomik yapısı olduğu söylenebilir. Örneğin ilkokul müdürü bir katılımcı, "Kazanımların öğrenciler tarafindan edinilme düzeyi merkeze ve kırsala göre değişmektedir. Merkezde ilgi daha fazla olduğundan kazanımların öğrenciler tarafindan edinilme düzeyi ve kalitesi artmaktadır." şeklinde düşüncesini açıklarken bir başka katılımcı ise "Kazanımların kalitesi ve düzeyi çok yüksek değil. Öğrencilerin buna hazırbulunuşluk düzeyi de çok iyi değil. Türkçe bilmeyen öğrenciye ingilizce, dört işlemi bilmeyene trigonometri öğretmek mümkün müdür?" şeklinde düşüncesini açıklamaktadır.

Katlımcılardan bazıları kazanımların edinilme düzeyini ve kalitesini, öğretmenlerin kazanımlar hakkındaki bilgilerinin yetersizliğine ve bu kazanımları edindirebilecek mesleki yeterlikten yoksun olduklarına bağlamaktadır $(\mathrm{N}=11)$. Örneğin bir katılımcı bu konuda görüşlerini şu şekilde dile getirmiştir: "Öğretmenlerin bu konuda hazırlıklı ve tam donanımlı olduklarını düşünmüyorum." Bir başka katılımcı ise "Öğretmenin öğretim programına ne kadar vakıf olduğu ile doğru orantılıdır" şeklinde görüşünü ifade etmiştir.

Katılımcılara "kazanımların gerçekleşme durumuyla ilgili hesapveriyor musunuz? Veriyorsanız kime hesapveriyorsunuz?" sorusu yöneltilmiş ve alınan cevaplar incelenmiştir. Kathlımcıların çoğu ( $N=12)$ öğretimsel hesapvermediğini ifade etmektedir. Katılımcılardan ikisi kısmen hesapverildiğini belirtirken geri kalan alt katlımcı da hesapverdiklerini belirtmektedirler. Hesapverdiğini ifade eden yöneticilerin öğretimsel alandan daha çok yönetimin diğer alanlarına yö- 
nelik hesapverdikleri söylenilebilir. Bu konuda okul yöneticilerinden biri şu görüşü ifade etmiştir: "Bütün kazanımlardan olmasa bile belli konularda yapılan çalışmalar ve sonuçları hakkında üst yöneticilere bilgiler aktarılmaktadır." Bir başka yönetici ise "Hesapverdiğimiz kişs çok ancak kazanımla alakalı değil. Öğretim kalitesi açısından velilere hesapverme durumumuz oluyor." şeklinde görüşünü belirtmiştir. Hesapverilenler çoğunlukla "Veli (14 kez) ve üst yönetici (11 kez)" şeklinde belirmektedir. Diğerleri ise müfettiş (4 kez), öğrenci (2 kez), okul aile birliği üyeleri (1 kez) şeklinde sıralanmaktadır. Hesapvermediğini ifade edenler arasından bir yönetici düşüncesini şu şekilde belirtmiştir: "Şu andaki MEB hesapverebilirliği minimize etmiştir. 657 değişmedikçe, kadrolu öğretmenler sözleşmeli olmadıkça kimseye hesap vermiyoruz." Katılımcılara yöneltilen "Kimler sizden hesap soruyor?" sorusuna karşılık katılımcılar en çok velilerin (10 kez), üst yöneticilerin (8 kez) müfettişlerin (5 kez), öğretmenlerin (2 kez) ve öğrencilerin (1 kez) hesap talep ettiklerini belirtmişlerdir. Bu kapsamda bir yönetici "Müfredattaki kazanımlarla ilgili olarak yılsonu raporlarında üst yöneticilere hesap veriyoruz." şeklinde görüşünü dile getirmiştir. Beş katılımcı ise "öğretimsel hesapverebilirlik konusunda kimsenin böyle bir talepte bulunmadığını" belirtmişlerdir. Örneğin katılımcılardan biri "Bu konuda bizden bir şey istenmiyor." Bir başkası "talep eden kimse yok." şeklinde görüşünü dile getirmiştir.

Katılımcılara "programdaki kazanımların öğrenciler tarafindan edinilmesi konusunda verilen hesabın yeterli olduğunu düşünüyor musunuz? Gerekçelendirebilir misiniz?" sorusu yöneltilmiş ve alınan cevaplar incelenmiştir. Görüş bildirenlerin neredeyse tamamı (14'e karşı 3) "yetersiz" olduğunu belirtmişlerdir. Verilen hesabı yeterli gören bir katılımcı görüşünü şu şekilde ifade etmiştir: "Yeterli, her yıl okulumuzun talep görmesi artıor. Veliler ve öğrenciler donanımlı ve mutlu şekilde okuldan ayrılıyorlar." Bu görüş bağlamında okul müdürü öğretimsel hesapverebilirliği, öğrenci kazanımlarına değil velilerin ve öğrencilerin okuldan memnun olmalarına bağlamaktadır. Bu durum yöneticinin öğretimsel hesapverebilirlik kavramını farklı bir alana taşıdığını göstermektedir. Bu da kavramın tam anlaşılamamasına bağlanabilir. Hesapvermenin yeterli olmadığını düşünen bir katılımcı görüşünü şu şekilde dile getirmiştir: "Müfredattaki kazanımların öğrenciler tarafindan edinilmesi konusunda verilen hesap yeterli değil. MEB performans değerlendirmesini sürekli yapmalı ve değerlendirmeli. Mesleki hizmetiçi kurslarına ağırlık vermeli." Bir başka yönetici ise aynı konuda "Bu konuda hesap verme söz konusu olmadığı için yeterli olduğunu düşünmüyorum. Öğretmenlere hangi kazanımı verdin-vermedin gibi bir soru sorulmuyor." şeklinde görüşünü açıklamaktadır.

\section{Tartışma, Sonuç ve Öneriler}

Bu çalışmada okul yöneticilerinin deneyimleri temelinde okullarda öğretimsel hesapverebilirlik olgusu incelenmiştir. Çalışma perspektifi olarak HS-V sürecinin temel ögeleri (bilinç, ne, kim, nasıl, sonuç) kullanılmıştır.

Okullarda "hesapverebilirlik" olgusunun dikkat çeken, deneyimlenen bir olgu olmadığı; okulların diğer meşguliyetlerinin arasında bu olgunun henüz yer bulamadığı saptanmıştı. Genel olarak hesapverebilirlik ve özel olarak öğretimsel hesapverebilirliğin tam kavranmadığı belirlenmiştir. Benzer saptama önceki çalışmalar tarafindan da yapılmıştır (Acar, 2013; Bülbül, 2011; Kardaş, 2016; Özen, 2011). Bu durumun yaşanmasında eğitim sistemi genelinde hesapsorma-verme uygulamalarının işlevsellik kazanmaması temel bir sebep olarak düşünülebilir. Okul yöneticilerine göre kazanımlar tam olarak edindirilememektedir. Temel sebepler, öğrenci kaynaklı, öğretmen kaynaklı, öğretim programı kaynaklı olarak sıralanmaktadır. Ayrıca kazanımların edindirilmesine gereken önemin atfedilmediği anlaşılmaktadır. Kazanımların öğretime aktarılması kapsamında öğrencilerin hazırbulunuşluk seviyeleri, yerleşim yeri farklılıkları ve öğretmenlerin mesleki tutum ve uygulamaları en sık dile getirilen engellerdir. Öğretmen kaynaklı sebepler arasında öğretim programını tam bilmeme, mesleki yetersizlik sıralanmaktadır. Yöneticiler kendilerinin ve öğretmenlerin programdaki kazanımlar hakkında tamamıyla bilgi sahibi olmadıklarını söylemektedirler. Bu durum okullardaki hesapverebilirlik uygulamalarını tamamen sorunlu hale getirmektedir. Öte yandan, kazanım sayısının fazlalığı, kazanımların öğrencilerin ilgi ve ihtiyaçlarına uygun olmaması öğretim programı kaynaklı engeller olarak dile getirilmektedir. Kazanımların edindirilmesine atfedilen değerin, akademik başarıya verilen değerin gerisinde kaldığı vurgulanmaktadır. Bu durumun temel sebebi olarak akademik başarının hayatta bir karşılığının olması (sınavda başarıya bağlı daha iyi gelecek elde etme beklentisi) gösterilebilir.

Kathlımcıların çoğunluğunun herhangi bir kişi ya da birime, kazanımların edindirilme düzey ve kalitesi hakkında hesap vermediği, hesap verdiğini ifade edenlerin de en çok velilere ve üst yöneticilere hesapverdikleri saptanmıştır. Yöneticilerden en çok veliler ve üst yöneticiler hesap sormaktadırlar. Ertan-Kantos (2010) tarafindan yapılan çalışmada sıklık düzeyine göre sırasıyla öğretmen ve yönetici hesapvermesi gereken kişiler olarak bulunmuştur. Aynı çalışmada kime hesapverilecek sorusu karşılığında yönetici, veli ve öğrenci yanıt alınmıştı. Bakioğlu ve Salduz (2014), tarama yöntemiyle ortaöğretim kademesindeki öğretmenlerin, öğrencilerin başarısı açısından kendilerini hesapverebilir görme durumlarını incelemişler ve öğretmenlerin hesapverebilirliği içselleştirmedikleri ve öğrenci başarısına ya da başarısız- 
Iığına ilişkin büyük oranda vicdanlarına hesapverdikleri sonucuna ulaşmışlardır. Mesleki hesapverebilirlik yaklaşımına göre okullar, üst yönetimlere ve ailelere hesapvermelidir (Leithwood vd., 2002). Fakat akademik performansa dayalı hesapverebilirlik aileler ve üst bürokratik yönetim tarafindan okullar üzerinde bir baskı aracına dönüştürülebilmektedir (Erdağ, 2017). Bu tür durumları önleyebilmek için içsel ve dışsal hesap verebilirlik ölçütleri ve ilkelerinin kullanılması önerilmektedir (Gündüz ve Göker, 2017). Öte yandan yöneticilerin, hesapverilecek kişilerin nitelikleri hakkında da kuşkuları saptanmıştır. Bu durum yönetici görevlendirmelerinde liyakati işaret etmektedir.

Okul yöneticileri kazanımların gerçekleştirilme durumuna ilişkin olarak hesapvermenin gerekli olduğu konusunda hemfikir olmalarına karşın ÖHS-V'nin gerçekleşmediğini bildirmişlerdir. Bu sonuç, okullarda sistematik bir hesapverebilirliğin gerçekleştirilmediğine ilişkin önceki çalışmaların sonuçlarıyla uyumludur (Acar, 2013; Bülbül, 2011; Kardaş, 2016; Özen, 2011). Hesapverme kültürünün oluşması için yasal zemini olan sistematik bir işleyişin tanıtılmasına ihtiyaç bulunmaktadır. Acar (2013)’ın vurguladığı gibi “... yapılması gereken hesapverebilirlik sisteminin dizayn edilmesidir”. Ertan-Kantos (2010)'un bulgularına göre hesapvermenin temel gerekçesi olarak mesleki etik ve yasal zorunluluk en sıklıkla vurgulanmıştır. Buradan hareketle hesapverebilirliğin eğitim camiasında meşruiyet kazandığı (Kalman ve Gedikoğlu, 2014) fakat sistematik bir işleyişin eksik olduğu vurgulanabilir (Bülbül ve Demirbolat, 2014).

Okul yöneticileri öğretimsel anlamda hesapvermenin yeterli olmadığı görüşündedirler. Temel gerekçeler olarak "ölçülebilir, nesnel veri eksikliği" ve "hesap vermeye bağlı yaptırımın tanımlanmaması" şeklinde belirtmişlerdir. Ertan-Kantos (2010) yönetici ve öğretmenlere yönelttiği "Nasıl hesapverilmelidir?” sorusuna karşılık devlet okullarında ilk sırada "bölge, şehir, okul genelindeki test sonuçlarına göre hesapverilmelidir" yanıtını alırken; özel okullarda ise "öğrenci davranış gelişimine göre hesapverilmelidir" cevabını ilk sırada saptamıştır. ÖHS-V için öğretim programlarında yer alan kazanımlar bir referans niteliği taşımasına karşın kazanımların öğretime aktarılması ve edinim durumunun ölçülmesi öne çıkan sorunlu alanlardır. Eğitimde hesapverebilirlik modellerinde öğrenci kazanımlarının ölçülmesi kritik alanların başında gelmektedir (Ertan-Kantos, 2010). Ulusal düzeyde ya da okul düzeyinde yapılan çoktan seçmeli test türü sınavların öğrenci kazanımlarını tam anlamıyla saptayabilecek nitelikte olmadığı belirtilmektedir (Darling-Hammond, 2007; Özen, 2011; TEDMEM, 2014; Ladd, 2016). Bu çalışmada, öğretmen ve yöneticiler, öğrenci kazanımları öğretim programındaki kazanımlarla değerlendirmenin zorluğunu gerekçe göstererek, öğrenci sonuçlarına dayalı hesapverebilirliği sorunlu olarak nitelemişlerdir. Bu araştırmada saptanmış olduğu gibi Özen (2011)'in çalışmasında da katılımcıların kendi değerlendirme sonuçlarını dikkate almayıp ulusal düzeyli sınav sonuçlarını dikkate almaya odaklandıkları belirlenmiştir. Ulusal veya okul düzeyli test temelli hesapverebilirlik yerine, öğrenci öğrenmesini geliştirmeye odaklı farklı değerlendirme yaklaşımlarını harmanlayarak kullanan denetim sistemlerinin tasarlanması ve işletilmesinin öğrenci gelişimi açısından daha etkili olduğu bildirilmektedir (Elgart, 2016; Kardaş, 2016; Ladd, 2016). Dezavantajlı kesimler (Parkes ve Stevens, 2003), öğrencilerin bireysel farklılıkları da dikkate alınarak öğretmenlerin bu öğrencilere sağladığı öğrenme-gelişme imkânları ve onların kazanımları edinme durumu temel alınmalıdır (Darling-Hammond, 2007). Özen (2011) tarafindan da önerildiği üzere hesapverebilirliğe ilişkin tüm veriler sınıf ve okul düzeyinde üretilebilir.

Belirlenen olumsuzluklara karşın okullarda hesapsorma-verme potansiyeli mevcuttur. Bu potansiyeli harekete geçirebilmek için özellikle okul yöneticilerinin ve öğretmenlerin "hesapverebilirlik” hakkında bilinç kazanmaları, bilgi ve becerilerinin geliştirilmesi gerekmektedir. Hesap sorma konumunda olanların hangi alanlarda ve nasıl hesap soracaklarını bilmemeleri bu önemli işlevi yerine getirmeyi engellemektedir. ÖHS-V için mutlaka sınav sonuçlarına ihtiyaç olmadığı; sınıfta gözlem, öğrencilerle sohbet, öğretmenlerle öğretim üzerinde konuşma, velilerle görüşme gibi bilgi edinme yollarıyla öğretim hakkında veri toplamak mümkündür (Baştürk, 2014; Gömleksiz ve Erkan, 2016). Ayrıca zümre çalışmalarından öğretimsel hesapverebilirlik açısından faydalanılabilir. Mesleki hesapverebilirlikte "profesyonel adalet, uzman bilgisi, içsel raporlar" kullanılabilmektedir (Ertan-Kantos, 2010). Çağdaş denetim, bireysel öğretmenin ders denetimi yerine, odağını zümrelere yöneltmiştir (Sergiovanni ve Starratt, 2007). Zümredeki öğretmenler kazanımların edinim düzey ve kalitesi hakkında geçerli ve güvenilir veri sağlayabilir ve bu test temelli hesapverebilirlikten kaynaklı sınırlılıkları gidermede bir katkı sağlayabilir. Kazanımlar içinde kritik önemde olanlar temsilci olarak kullanılabilir. Öğretiminde zorluk çekilen kazanımlar belirlenerek özel araştırma ve görüşme ya da başka okullarda gözlemlerle daha etkili öğretim etkinlikleri belirlenebilir.

Kazanımlara ilişkin resmi raporlamaların (karne, takdir belgesi, yılsonu raporları gibi) geçerli ve güvenilir olmadığı belirtilmiştir. Eğitimde hesapverebilirlik açısından önemli olan bu tür belgelendirmelerin (Anderson, 2005) gerçeği yansıtacak şekilde düzenlenmesinin önemi vurgulanmalıdır. Ayrıca hesapverebilirliğin yasal temellerinden birini oluşturan stratejik plan hazırlanması sürecinde okullarda öğretimsel hedefler ve bu kapsamda kazanımların edinilmesinin odağı oluşturması beklenmektedir. Okulların stratejik planlarında belirlenen hedeflerin gerçekleşme durumunun dikkate alınmadığı saptanmıştır (Özen, 2011). Bu çalışmada “okulların yönetimsel anlamda fiziki çevrenin düzenlenmesi ve yazış- 
maların zamanında yapılması odaklı çalışıyor" izlenimi edinilmiştir. Sonuçlar dikkate alındığında okullarda hazırlanan stratejik planların odağında okulun öğretimsel hedeflerinin olmadığı ileri sürülebilir. Türk eğitim sisteminde öğrenci öğrenmesi odağından uzaklaşıldığı, bir amaç kayması ya da amaç gölgelenmesinin yaşandığı belirtilebilir (Kardaş, 2016).

İşlevsel HS-V için üst yasal düzenlemelerin varlığı ve eğitim paydaşlarının kabulü (Ertan-Kantos, 2010) dikkate alınarak hesapverebilirliği işler kılabilecek yasal ve sistematik bir mekanizmaya ihtiyaç duyulmaktadır. Okullarda eğitim kalitesinin iyileştirilmesi için MEB tarafından uygulanabilir bir ÖHS-V mekanizmasının geliştirilip tanıtılmasına ve izlenmesine ihtiyaç bulunmaktadır.

Bu çalışma, elde edilen sonuçları genelleme iddiasında değildir çünkü Aksaray ili özelinde ve yalnızca devlet okullarındaki yöneticiler üzerinde gerçekleştirilmiştir. Türkiye'nin farklı bölgelerinde, özel okullarda, farklı örneklem gruplarında (örneğin öğretmenler) yapılacak çalışmalarda farklı sonuçlar alınabilir. Bu çalışmadan yararlanacak sonraki araştrrmacılara yönelik olarak, veri toplamada etkileşimli ortamlar (odak grup görüşmesi) ile etkileşimsiz ortamlar (bireysel olarak gerçekleştirilen yarı-yapılandırılmış görüşme) arasında bir fark olmadığı saptanmıştı. Bu nedenle veri toplamada bu iki yoldan birinin kullanılması yeterli olabilir. Öğretim sürecini analiz ederek burada yapılan işlemlerle ilgili ÖHS-V basamaklarını belirlemeye, bu basamaklarda kimin kime hesapvereceği ya da soracağına yönelik araştırmaların yapılması önerilir. Öğretimsel hesapverebilirlik açısından, mevcut öğretim uygulamalarında varolan ancak; standart ve sistematik olmayan uygulamaları belirlemeye yönelik çalışmaların yapılması önerilir. ÖHS-V olgusunun farklı örneklemlerde ve okuldaki farklı paydaşları da içerecek şekilde çalışılarak sonuçların karşılaştıııması önerilir. Buna ek olarak nicel ve nitel verileri harmanlayan karma yöntemin kullanılması önerilmektedir.

\section{Teşekkür}

Bu çalışmanın odak-grup görüşmesine ve yarı-yapılandııımış görüşmelere katılarak araştırmanın gerçekleştirilmesine destek olan okul yöneticilerine; çalışmanın olgunlaştrıımasında yapıcı önerileriyle destek olan hakemlere teşekkür ederiz.

\section{Kaynakça}

Acar, M. (2013). Eğitimde hesapverebilirlik. İçinde S. Özdemir (Ed.), Eğitim yönetiminde kuram ve uygulama (381-410). Ankara: PegemA Anderson, J.A. (2005). Accountability in education [Elektronik basım]. http://unesdoc.unesco.org adresinden erişilmiştir.

Bakioğlu, A. \& Salduz, E. (2014). Öğretmenlerin hesap verebilirliklerini öğrencilerin başarısı açısından değerlendirmeleri. Eğitim Bilimleri Dergisi, 40, 13-29.

Balcı, A. (2001). Etkili okul ve okul geliştirme. Ankara: PegemA

Baştürk, S. (2014). Eğitimde ölçme ve değerlendirme. Ankara: Nobel

Bülbül, M. (2011). Türk Milli Eğitim Sisteminde hesapverebilirlik (Yayımlanmamış doktora tezi). Gazi Üniversitesi Eğitim Bilimleri Enstitüsü, Ankara.

Bülbül, M \& Demirbolat, A. O. (2014). Hesap verebilillikle ilgili Türk Milli Eğitim Sistemine yönelik bir değerlendirme. Eğitim ve Bilim, 174, 39-52.

Çokluk, Ö., Yılmaz, K. \& Oğuz, E. (2011). Nitel bir görüşme yöntemi: odak grup görüşmesi. Kuramsal Eğitimbilim, 4 (1), 95-107.

Darling-Hammond, L. (2007). Race, inequality and educational accountability: the irony of 'No Child Left Behind', Race Ethnicity and Education, 10(3), 245-260, doi: 10.1080/13613320701503207

Elgart, M.A. (2016). Creating state accountability systems that helps schools improve. Kappan, 98(1), 26-30.

Erdağ, C. (2017). Accountability policies at schools: a study of path analysis. Educational Sciences: Theory and Practice, 17(4), 1405-1432.

Ertan-Kantos, Z. (2010). ilköğretim okulu yönetici ve öğretmenlerinin görüşlerine göre kamu ve özel ilköğretim okulları için bir hesapverebilirlik modeli (Yayımlanmamış doktora tezi). Ankara Üniversitesi Eğitim Bilimleri Enstitüsü, Ankara.

Fidan, N. \& Baykul, Y. (1994). Ilköğretimde temel öğrenme ihtiyaçlarının karşılanması. Hacettepe Üniversitesi Eğitim Fakültesi Dergisi, 10, 7-20.

Gömleksiz, M. \& Erkan, S. (2016). Eğitimde ölçme ve değerlendirme. Ankara: Nobel

Gündüz, Y. \& Göker, S. D. (2017). Eğitim denetimi sürecinde hesapverebilirlik ve şeffaflık uygulamaları. Ondokuz Mayıs Üniversitesi Eğitim Fakültesi Dergisi, 36 (1), 83-93.

Kalman, M. \& Gedikoğlu, T. (2014). Okul yöneticilerinin hesapverebilirliği ile örgütsel adalet arasındaki ilişkinin incelenmesi. Hacettepe Üniversitesi Eğitim Fakültesi Dergisi, 29(2), 115-128.

Karakaya, S. (2004). A comparative study: English and Turkish teachers' conceptions of their professional responsibility. Educational Studies, 30 (3), 200-205.

Kardaş, D.P. (2016). Eğitimde hesap verebilirliğe ilişkin model önerisi (Yayınlanmamış doktora tezi). Marmara Üniversitesi Eğitim Bilimleri Enstitüsü, i̇stanbul.

Ladd, F.H. (2016). Now is the time to experiment with inspections for school accountability. Education Digest, 82 (3), 51-54. 
Leithwood, K., Steinbach, R. \& Jantzi, D. (2002). School leadership and teachers' motivation to implement accountability policies. Educational Administration Quarterly, 38(1), 94-119.

Millî Eğitim Bakanlı̆̆ (2018a). Okul Öncesi Eğitim ve Illköğretim Kurumları Yönetmeliği [Mevzuat]. http://mevzuat.meb.gov.tr/ adresinden erişildi. Millî Eğitim Bakanlığı (2018b). Ortaöğretim Kurumları Yönetmeliği [Mevzuat]. http://mevzuat.meb.gov.tr/ adresinden erişildi.

OECD (2014). TALIS 2013 results: an international perspective on teaching and learning. Paris: OECD Publishing.

OECD (2016). Education at a glance. Paris: OECD Publishing

Özen, F. (2011). Illköğretim okulu yönetici ve öğretmenlerinin görüşlerine göre okul geliştirme aracı olarak hesapverebilirlik (Yayınlanmamış doktora tezi). Ankara Üniversitesi Eğitim Bilimleri Enstitüsü, Ankara.

Öntaş, T. \& Atmaca, T. (2016). Eğitim ve ideoloji bağlamında hesap verebilirlik ve neoliberalizm bağlantısı. Turkish Studies, 11 (3), $1813-1823$. Parkes, J. \& Stevens, J.J.(2003) Legal issues in school accountability systems. Applied Measurement in Education, 16(2), $141-158$.

Schlechty, P. C. (2005) Okulu yeniden kurmak. (Çev. Y. Özden). Ankara: Nobel.

Sergiovanni, T. \& Starratt, R. (2007). Supervision: a redefinition. New York: McGraw Hill.

Şimşek, H. \& Yıldırım, A. (2011). Sosyal bilimlerde nitel araştırma yöntemleri. Ankara: Seçkin.

TEDMEM (Türk Eğitim Derneği Eğitim Faaliyetleri Birimi) (2014). PISA 2012, Türkiye üzerine değerlendirmeler ve öneriler. Ankara: Öncü Matbaası. 